\title{
Peningkatan Kemampuan dan Kemandirian Pengentasan Stunting melalui Pemberdayaan Petani Desa Sukogidri Kecamatan Ledokombo Jember
}

\author{
Erma Sulistyaningsih ${ }^{1}$, Pulong Wijang Pralampita ${ }^{1}$, Parawita Dewanti $^{2}$ \\ sulistyaningsih.fk@unej.ac.id \\ ${ }^{1}$ Fakultas Kedokteran, ${ }^{2}$ Fakultas Pertanian, Universitas Jember
}

\begin{abstract}
Abstrak
Angka stunting di Kabupaten Jember cukup tinggi di Propinsi Jawa Timur. Desa Sukogidri merupakan salah satu desa penyumbang stunting di Kabupaten Jember. Secara umum, kegiatan pengabdian ini bertujuan untuk membantu menyukseskan program pemerintah dalam menurunkan angka stunting di Kabupaten Jember, dengan tujuan khusus antara lain untuk meningkatkan kesadaran masyarakat akan stunting dan bahayanya, meningkatkan pengetahuan tentang pencegahannya serta meningkatkan kemandirian untuk pengentasan stunting dengan melatih tentang penanaman sistem hidroponik. Solusi yang diberikan oleh tim pelaksana pengabdian berupa kegiatan pendidikan dan penyuluhan serta pelatihan penyiapan menu sehat. Selain itu juga transfer pengetahuan tentang penanaman sistem hidroponik dan pemberian sistem hidroponik yang dapat digunakan untuk menyediakan bahan pangan yang sehat. Di akhir kegiatan pengabdian dilakukan pembentukan model keluarga sadar gizi (KADARZI) yang dapat secara mandiri mengenali dan mengelola masalah-masalah gizi anggota keluarganya melalui upaya menimbang berat badan secara teratur, memberikan air susu ibu (ASI) eksklusif, mengkonsumsi makanan beraneka ragam, menggunakan garam beryodium serta mengkonsumsi suplemen gizi yang sesuai dengan anjuran.
\end{abstract}

Kata Kunci: stunting, gizi, kadar gizi, Sukogidri

\section{Abstract}

The prevalence of stunting in Jember Regency is quite high. Sukogidri village is one of the stunting contributing villages in Jember. In general, this public service activity aimed to support the government program to reduce stunting rates in Jember Regency and the specific objectives including increasing public awareness about stunting and its danger to health condition, increasing knowledge about prevention of stunting and increasing independence to alleviate stunting by training on planting hydroponic system and healthy menu preparation. The solution is provided by the service team including education and counseling activities, and training of healthy menu preparation. In addition, there was also transfer of knowledge about the planting of hydroponic system and the provision of hydroponic system that can be used to provide healthy food. At the end of the service activity, the team has developed the nutritionally aware family (KADARZI) model that can independently recognize and manage nutritional problems of family members by weighing regularly, provide exclusive breast feeding (ASI), consume diverse foods, use iodized-salt and consume supplements as recommended.

Keywords. stunting, nutritionally aware family model, Sukogidri

\section{PENDAHULUAN}

Stunting adalah kondisi dimana anak mengalami gangguan pertumbuhan sehingga anak lebih pendek dibanding anak-anak seusianya (Kementerian Desa, Pembangunan 
Daerah Tertinggal, dan Transmigrasi, 2017). Prevalensi stunting di Kabupaten Jember cukup tinggi. Data dari Dinas Kesehatan Kabupaten Jember menyebutkan angka stunting mencapai 29.020 anak atau sebesar 17,73\% dari total balita yang ada di Kabupaten Jember, yang tersebar di 31 kecamatan. Desa Sukogidri merupakan salah satu desa di Kecamatan Ledokombo yang turut menyumbangkan angka stunting di Kabupaten Jember (Dinas Kesehatan Pemerintah Kabupaten Jember, 2018).

Desa Sukogidri mempunyai jumlah penduduk total 3.634 orang dalam 1.266 kepala keluarga, dimana sejumlah 846 orang bekerja sebagai petani dan sebanyak 1.938 orang bekerja sebagai buruh termasuk buruh tani. Prosentase terbesar penduduk Desa Sukogidri berada pada usia produktif, sedangkan jumlah penduduk balita di Desa Sukogidri sebanyak 353 anak. Data terbaru menunjukkan angka stunting di Desa Sukogidri sebanyak 18 anak. Fasilitas kesehatan yang ada di Desa Sukogidri antara lain 1 buah polindes yang dikelola bidan dengan 4 buah posyandu dengan 5 orang kader tiap posyandu dan 1 buah posyandu lansia, sehingga ada 20 kader di seluruh Desa Sukogidri (Desa Sukogidri, 2017).

Permasalahan stunting merupakan permasalahan multi sektor, mulai dari sektor kesehatan, pertanian, ekonomi, sosial, dan lain-lain. Permasalahan tidak hanya berkaitan dengan persoalan gizi, beberapa hal lain yang terkait antara lain pola hidup sehat, menjaga kebersihan lingkungan, sanitasi air bersih dan perilaku masyarakat. Program yang dilakukan oleh pemerintah melalui Kementerian Kesehatan untuk menangani stunting yaitu melalui upaya perbaikan gizi meliputi intervensi gizi spesifik dan intervensi gizi sensitif. Intervensi gizi spesifik meliputi pemberian tablet tamba darah (TTD) dan promosi serta suplemen gizi makro dan mikro, penatalaksanaan gizi kurang/buruk, pemberian obat cacing dan zinc untuk manajemen diare. Sedangkan intervensi gizi sensitif dilakukan melalui pemantauan tumbuh kembang, penyediaan air bersih, pendidikan gizi, imunisasi, pengendalian penyakit, penyediaan jaminan kesehatan, Program Indonesia Sehat melalui Pendekatan Keluarga (PIS PK), Nusantara Sehat (NS) tenaga ahli gizi dan tenaga promosi kesehatan, tenaga kesling, dan akreditasi puskesmas dan rumah sakit (Komisi Ilmiah Badan Litbang Kesehatan, 2013).

Secara umum, kegiatan pengabdian ini bertujuan untuk membantu menyukseskan program pemerintah dalam menurunkan angka stunting di Kabupaten Jember. Selain itu, tujuan khususnya adalah untuk mengentaskan masalah stunting di Desa Sukogidri dengan melibatkan partisipasi aktif masyarakat menuju ke arah kemandirian dalam mengentaskan stunting. Kegiatan utama yang dilakukan antara lain pendidikan dan pelatihan untuk meningkatkan kesadaran masyarakat akan stunting dan bahayanya, meningkatkan pengetahuan tentang pencegahan stunting dan pelatihan penyiapan menu makanan yang sehat. Hal yang juga dilakukan adalah pendidikan dan pelatihan tentang potensi gangguan kesehatan akibat paparan kronis pestisida serta pelatihan tentang alternatif penanaman yang minimal menggunakan pestisida melalui sistem hidroponik diikuti dengan pemberian sistem hidroponik yang dapat digunakan untuk menyediakan bahan pangan yang sehat. Di akhir kegiatan pengabdian dilakukan pembentukan model keluarga sadar gizi (KADARZI), yaitu model keluarga dimana seluruh anggota keluarganya berperilaku gizi seimbang, mampu mengenali masalah kesehatan dan gizi dan mampu mengambil langkah untuk mengatasi masalah gizi anggota keluarganya. Ciri-ciri model keluarga KADARZI antara lain menimbang berat badan secara teratur, memberi air susu ibu (ASI) eksklusif kepada bayi baru lahir sampai 6 bulan, mengkonsumsi makanan beraneka ragam, menggunakan garam 
beryodium dan mengkonsumsi suplemen gizi sesuai anjuran (Direktorat Bina Gizi Masyarakat, 2007).

\section{METODE INTERVENSI}

Kegiatan pengabdian ini dilakukan dengan melibatkan stakeholder yaitu pemerintahan Desa Sukogidri serta para kader kesehatan desa. Kegiatan ini terdiri dari beberapa tahapan, melalui pendidikan dan pelatihan dengan tujuan akhir meningkatkan kemandirian masyarakat dalam mencegah terjadinya stunting dengan melibatkan semua aspek mulai dari perangkat desa, petugas kesehatan, kader, petani dan masyarakat. Tahapan kegiatan yang dilakukan adalah sebagai berikut:

1. Penyuluhan tentang stunting dan bahayanya untuk perangkat desa, kader posyandu, tokoh masyarakat, petani dan masyarakat.

2. Penyuluhan tentang upaya mencegah stunting dan pelatihan penyiapan menu sehat untuk perangkat desa, kader posyandu, keluarga enderita stunting, ibu hamil dan masyarakat.

3. Penyuluhan tentang bahaya paparan pestisida terhadap kesehatan dan pemeriksaan kesehatan dengan sasaran perangkat desa, kader posyandu, tokoh masyarakat, petani dan masyarakat

4. Pelatihan tentang sistem pertanian hidroponik dan pemberian sistem hidroponik ke perwakilan desa dengan sasaran perangkat desa, kader posyandu, tokoh masyarakat, petani dan masyarakat.

5. Pembentukan model keluarga sadar gizi (KADARZI) untuk masyarakat Desa Sukogidri.

Kegiatan pengabdian ini dilaksanakan pada bulan September- November 2018.

\section{HASIL DAN PEMBAHASAN}

Kegiatan pengabdian dilakukan bulan September-November 2018 oleh tim dosen dari Fakultas Kedokteran dan Fakultas Pertanian Universitas Jember. Sebelum kegiatan inti pengabdian, terlebih dahulu dilakukan survei lokasi dan pendekatan kepada perangkat desa dan masyarakat untuk menggali persoalan utama yang dihadapi oleh masyarakat Desa Sukogidri berkaitan dengan kasus stunting. Diketahui bahwa masalah stunting merupakan permasalahan yang harus diselesaikan lintas sektoral melibatkan bidang kesehatan, bidang pertanian, bidang sosial kemasyarakatan, dan lain-lain mengingat penderita sunting tidak semua berasal dari masyarakat sosioekonomi rendah. Hal ini sesuai dengan yang disampaikan oleh Dinas Kesehatan Kabupaten Jember bahwa daya ungkit Dinas Kesehatan untuk mengatasi permasalahan stunting hanya $30 \%$, sedang $70 \%$ sisanya berada di sektor lain seperti pertanian dan umum.

Kegiatan pertama yang dilakukan adalah penyuluhan tentang stunting dan bahayanya. Gambaran kegiatan dapat dilihat pada gambar l. Kegiatan ini diikuti oleh 28 orang peserta yang terdiri dari perangkat desa, kader posyandu, tokoh masyarakat, petani dan masyarakat umum. Masyarakat diberikan informasi yang lengkap tentang pengertian stunting dan disadarkan tentang bahaya yang ditimbulkan akibat stunting. Stunting bukan hanya mempengaruhi ukuran atau tinggi badan anak, tetapi juga dapat mempengaruhi kecerdasan karena menghambat perkembangan otak an fisik, menimbulkan kegemukan sehingga rentan mengidap berbagai penyakit termasuk penyakit tidak menular. Pada saat dewasa, penderita stunting juga dapat mengakibatkan 
prestasi yang kurang bagus. Oleh karena itu, stunting bukan hanya masalah ringan, tetapi merupakan masalah besar yang perlu dipecahkan secara bersama-sama.

Kegiatan berikutnya yang dilakukan adalah penyuluhan tentang upaya mencegah stunting dan pelatihan penyiapan menu sehat. Kegiatan dihadiri oleh 30 peserta yang terdiri dari perangkat desa, petugas kesehatan, kader posyandu, ibu-ibu. Upaya yang dilakukan untuk mencegah stunting antara lain mengkonsumsi makanan dengan gizi seimbang untuk ibu hamil, melakukan pemeriksaan minimal 4 kali selama kehamilan untuk ibu hamil, memberikan stimulasi untuk janin dalam kandungan, memberikan ASI eksklusif, dilanjutkan dengan makanan pendamping ASI (MP-ASI) sampai 2 tahun, mengenalkan makanan bergizi pada anak sesuai dengan usia, dan memberikan stimulasi kepada anak sesuai usia dan memantau perkembangan anak dengan kartu kembang anak (KKA); dimana kegiatan tersebut dilakukan pada 1000 hari pertama kelahiran (HPK). Selain itu, juga dilakukan kegiatan pelatihan penyiapan menu sehat, dalam hal ini dilatih menyiapkan menu puding labu mawar jeruk. Resep ini dipilih karena banyak labu dihasilkan di Desa Sukogidri dan belum dimanfaatkan dengan baik karena pengolahannya yang terbatas. Semua bahan dapat ditemukan dengan mudah di Desa Sukogidri, proses pembuatannya juga mudah dan menghasilkan bentuk dan cita rasa yang disukai anak-anak, sehingga dapat dikonsumsi anak-anak untuk memperbaiki status gizi anak stunting. Resep diajarkan untuk diterapkan pada kegiatan posyandu.

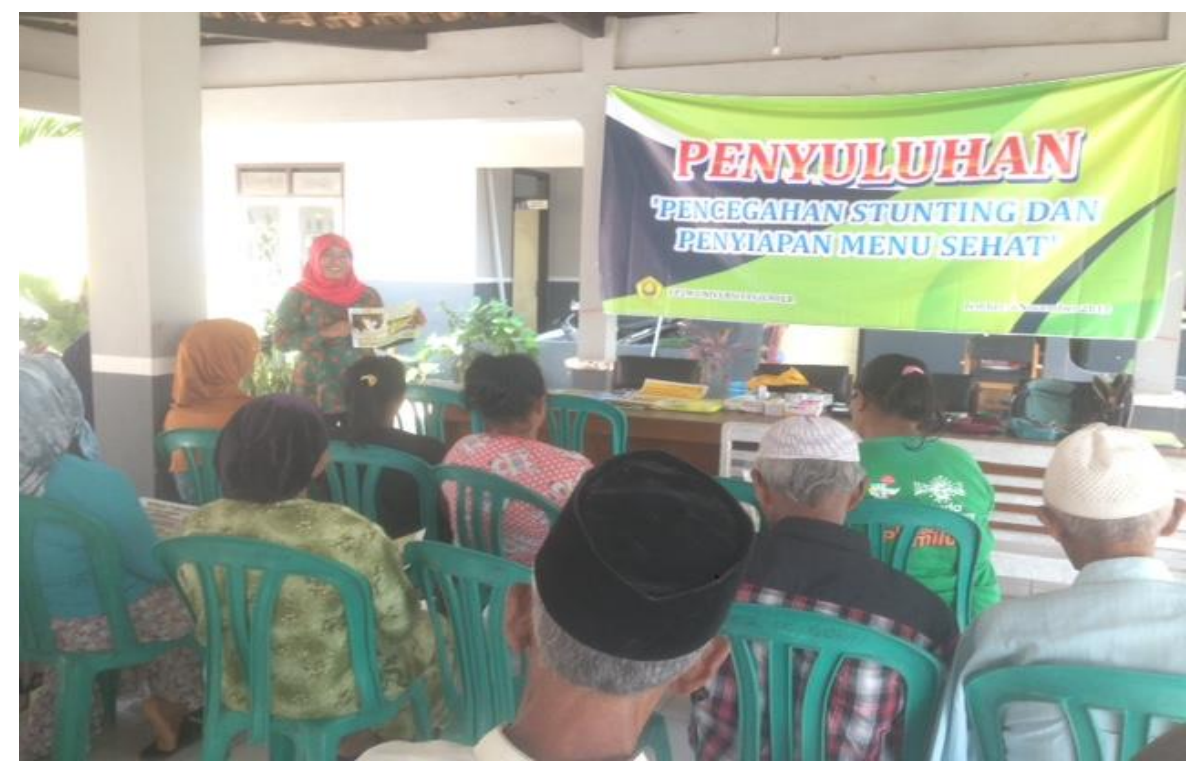

Gambar l. Penyuluhan tentang stunting dan bahayanya di Balai desa Sukogidri

Kegiatan berikutnya adalah penyuluhan tentang bahaya paparan pestisida terhadap kesehatan dan dilanjutkan dengan pemeriksaan kesehatan. Kegiatan ini dihadiri oleh 35 peserta yang terdiri dari perangkat desa, kader posyandu, petani, dan masyarakat umum. Dalam kegiatan penyuluhan disampaikan bahaya yang mengancam akibat penggunaan pestisida pada pertanian terhadap kesehatan. Juga ditunjukkan gejala-gejala yang dapat diderita saat mengalami keracunan ringan sampai berat akibat pestisida, meliputi gejala pusing, sakit kepala, mual, muntah, diare, berkeringat banyak dan banyak berair liur. Pada kondisi keracunan berat dapat terjadi pingsan dan tidak sadarkan diri. Selain itu juga dijelaskan cara-cara untuk meminimalisir dampak negatif pestisida, meliputi penggunaan alat pelindung diri (APD) yang terdiri dari baju dan 
celana panjang, sarung tangan, masker, penutup kepala dan sepatu. Upaya lain adalah dengan menyemprotkan pestisida sesuai dengan arah angin yang bertiup. Kegiatan diikuti dengan pemeriksaan kesehatan meliputi tekanan darah, denyut nadi, frekuensi nafas dan gula darah acak. Ditemukan beberapa orang mempunyai tekanan darah tinggi dan gula darah yang tinggi, untuk mereka disarankan ke puskesmas untuk mendapat pemeriksaan dan pengobatan lebih lanjut.

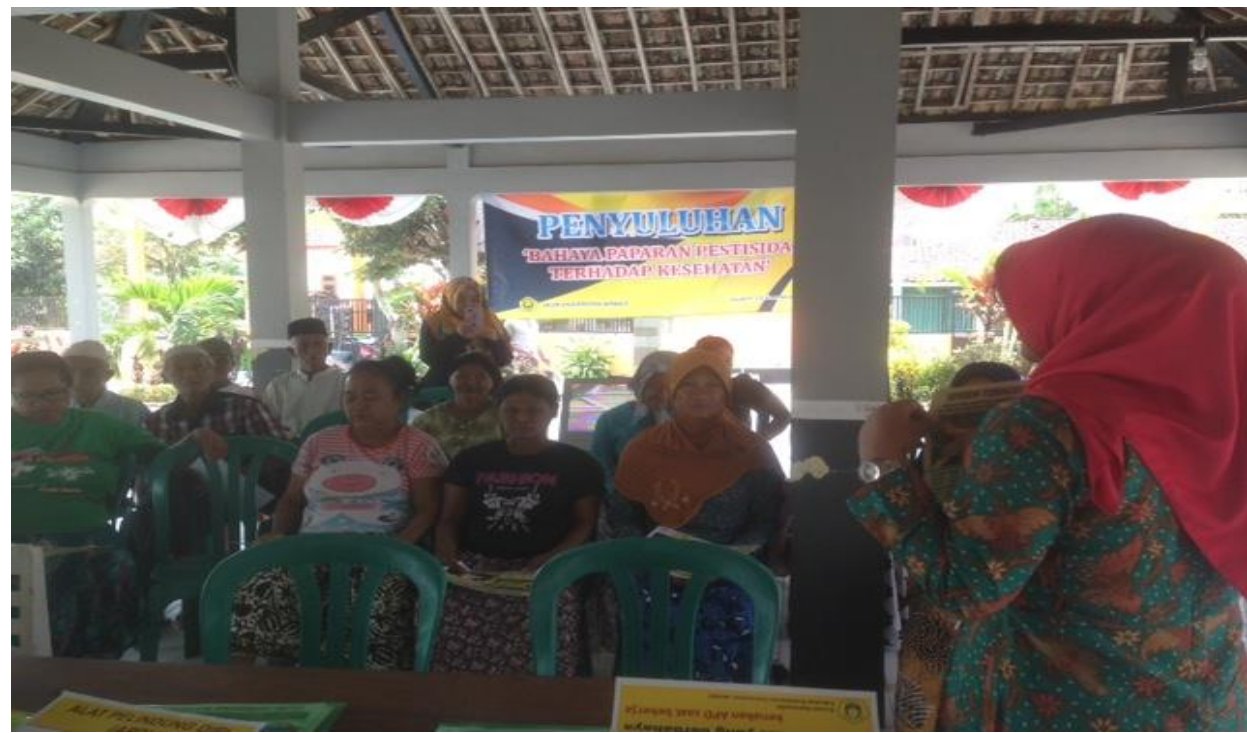

Gambar 2. Penyuluhan tentang bahaya paparan pestisida dan pemeriksaan kesehatan di Balai desa Sukogidri

Kegiatan lain yang dilakukan adalah pelatihan tentang sistem pertanian hidroponik ke perwakilan desa dengan sasaran perangkat desa, kader posyandu, tokoh masyarakat, petani dan masyarakat sejumlah 50 orang dan dilanjutkan pemberian sistem hidroponik ke perwakilan Desa Sukogidri. Sistem pertanian hidroponik dapat menjadi alternatif pertanian yang meminimalkan penggunaan pestisida. Sistem pertanian ini juga digunakan untuk mendukung kegiatan pencegahan stunting dengan menyediakan bahan pangan yang bervariasi dan mempunyai nilai gizi yang baik guna mendukung gerakan pemberian makanan yang bervariasi. Seperti disampaikan Kementerian Kesehatan bahwa permasalahan stunting bukan hanya masalah ekonomi, tetapi juga pola asuh yang juga melibatkan ketersediaan bahan pangan yang sesuai kebutuhan gizi.

Kegiatan terakir yang dilakukan adalah pembentukan model keluarga sadar gizi (KADARZI). Kegiatan ini sebagai puncak kegiatan pengabdian, dengan menetapkan beberapa keluarga sebagai model KADARZI. Keluarga model ini diarapkan mampu memotivasi keluarga-keluarga lain untuk mencegah masalah stunting di Desa Sukogidri.

\section{PENUTUP}

\section{A. Kesimpulan}

Tim pelaksana pengabdian masyarakat telah melakukan upaya peningkatan kesadaran dan kemandirian masyarakat Desa Sukogidri dalam mencegah dan mengatasi masalah stunting yang terjadi di desa tersebut melalui penyuluhan, pendidikan, pelatihan, pemberian alat dan pembentukan model KADARZI. Penyuluhan yang dilakukan tentang stunting, bahaya, dan pencegahannya, juga penyuluhan faktor lain yang ikut 
berperan, yaitu tentang bahaya pestisida yang dapat mengganggu kesehatan dan upaya meminimalisirnya. Pelatihan yang diberikan tentang penyiapan menu sehat dan sistem pertanian hidroponik serta pemberian sistem hidroponik yang dapat digunakan dalam rangka meningkatkan kemandirian pengentasan masalah stunting serta pembentukan model keluarga sadar gizi. Upaya-upaya yang dilakukan diharapkan dapat meningkatkan kemandirian masyarakat Desa Sukogidri untuk mengatasi masalah stunting.

\section{B. Saran}

Kegiatan ini sangat baik dilakukan dalam rangka mendukung program pemerintah untuk mengatasi stunting. Keberlanjutan program ini sangat diperlukan agar program kemandirian dan pemberdayaan masyarakat terus dapat dilanjutkan sehingga masyarakat Desa Sukogidri bebas stunting dan nantinya dapat pula diterapkan di desadesa lain yang mempunyai masalah serupa.

\section{Ucapan Terima kasih}

Terima kasih kepada Universitas Jember yang telah mendanai kegiatan pengabdian masyarakat ini melalui Hibah Pengabdian kepada Masyarakat skim Pengabdian Kemitraan (PPK) tahun anggaran 2018.

\section{DAFTAR PUSTAKA}

Desa Sukogidri. Profil Desa Sukogidri Kecamatan Ledokombo Kabupaten Jember. (Jember, 2017).

Departemen Kesehatan Republik Indonesia. Cegah stunting dengan perbaikan pola makan pola asuh dan sanitasi. online (http: www.depkes.go.id/article/view/18040700002/cegah-stunting-dengan-perbaikanpola-makan-pola-asuh-dan-sanitasi-2-html).

Direktorat Jenderal Bina Kesehatan Masyarakat. Direktorat Bina Gizi Masyarakat. Departemen Kesehatan. Pedoman Strategi KIE Keluarga Sadar Gizi (KADARZI). (Jakarta: Direktorat Bina Gizi Masyarakat, 2007).

Dinas Kesehatan Pemerintah Kabupaten Jember. "Kemenkes support Jember komitmen turunkan angka balita stunting". (2018), online: 〈jember,go,id/kemenkes-supportjember-komitmen-turunkan-angka-balita-stunting/>.

Kementerian Desa, Pembagunan Daerah Tertinggal, dan Transmigrasi. Buku saku desa dalam penanganan stunting. (Jakarta: Kementerian Desa, Pembagunan Daerah Tertinggal, dan Transmigrasi, 2017)

Komisi Ilmiah Badan Litbang Kesehatan. rancangan Agenda Riset Kesehatan Nasional 2013-2018. Rapat Kerja Badan Penelitian Pengembangan Kesehatan. (Jakarta: Komisi Ilmiah Badan Litbang Kesehatan, 2013). 